\title{
Clinical Trials in Traumatic Brain Injury: Past Experience and Current Developments
}

\author{
Andrew I. R. Maas,* Bob Roozenbeek, ${ }^{* \dagger}$ and Geoffrey T. Manley ${ }^{\S}$ \\ *Department of Neurosurgery, University Hospital 2650 Antwerp, Belgium; ${ }^{\dagger}$ Center for Medical Decision Making, Department \\ of Public Health, Erasmus MC, University Medical Center Rotterdam, 3000 CA, The Netherlands; ${ }^{\circledR}$ Department of Neurological \\ Surgery, University of California, San Francisco, California 94110
}

\begin{abstract}
Summary: In this article, we review past and current experience in clinical trials of traumatic brain injuries (TBIs), we discuss limitations and challenges, and we summarize current directions. The focus is on severe and moderate TBIs. A systematic literature search of the years from 1980 to 2009 revealed 27 large phase III trials in TBI; we were aware of a further 6 unpublished trials. Analysis of these 33 trials yielded interesting observations:
\end{abstract}

- There was a peak incidence of trial initiations that occurred in the mid-1990s with a sharp decline during the period from 2000 to 2004.

- Most trials that reported a significant treatment effect were studies on a therapeutic strategy (e.g., decompressive craniectomy, hypothermia), and these were single-center studies.

- Increasingly, studies have been shifting toward the Far East.
The currently existing trial registries permit insight into ongoing or recently conducted trials. Compared with the past decade, the number of studies on neuroprotective agents taken forward into efficacy-oriented studies is low. In contrast, the number of studies on therapeutic strategies appears to be increasing again.

The disappointing results in trials on neuroprotective agents in TBI have led to a critical reappraisal of clinical trial methodology. This has resulted in recommendations for preclinical workup and has triggered extensive analysis on approaches to improve the design and analysis of clinical trials in TBI. An interagency initiative toward standardization on selection and coding of data elements across the broad spectrum of TBI is ongoing, and will facilitate comparison of research findings across studies and encourage high-quality meta-analysis of individual patient data in the future. Key Words: Traumatic brain injury, randomized controlled trials, neuroprotection, methodology, standardization.

\section{INTRODUCTION}

Randomized controlled trials (RCT) are considered the gold standard for proving the efficacy of new treatments. In the field of traumatic brain injury (TBI), however, not a single multicenter phase III RCT on neuroprotective agents has convincingly shown benefit. ${ }^{1-3}$ As a consequence, a sense of disappointment prevails; basic science researchers are increasingly frustrated that their hard and promising work performed under clean experimental conditions does not seem to transfer into the "dirty" clinical situation, and there is some reluctance by pharmaceutical companies to embark on a new high-cost venture in TBI. However, trials conducted so far have not definitively established the lack of possible benefit.

Address correspondence and reprint requests to: Andrew I. R. Maas, M.D., Ph.D., Department of Neurosurgery, University Hospital Antwerp, Wilrijkstraat 10, 2650 Edegem, Belgium. E-mail: andrew.maas@ uza.be.
To the contrary, various trials have shown a trend toward efficacy, and this offers hope. Basic research has greatly advanced our knowledge of what happens in the brain after TBI, offering opportunities to limit processes involved in the development of secondary brain damage. Many experimental studies on a multitude of agents have shown encouraging results, demonstrating efficacy of different agents on histologic endpoints, intracranial pressure, brain edema, cerebral blood flow, metabolism, and also on functional outcome. Translating advances from basic research into clinical benefit has proven complex.

In the experimental situation, studies are performed under tightly controlled conditions. TBI in the clinical situation, however, includes a complex spectrum of pathologies, often superimposed with systemic second insults (e.g., hypoxia and/or hypotension). Approaches to treatment may vary, and uncertainty exists as to whether pathophysiologic processes targeted are indeed active in individual patients and, if so, at what time after injury. It 
is here that more basic and clinical research is needed before targeting therapy to the individual needs of a patient can become a clinical reality. TBI populations are also heterogeneous in terms of clinical severity and baseline prognostic risk. This heterogeneity poses complex methodological challenges. It is here that methodological approaches may be optimized to increase statistical power.

The challenge to demonstrate benefit of a novel agent or treatment strategy in TBI is great, but the rewards will be correspondingly high.

TBI is a field with one of the greatest unmet needs in medicine and public health. ${ }^{4}$ Not only is it a major cause of death and disability, incurring great personal suffering to victims and relatives, but it also leads to huge direct and indirect costs to society. In the United States, the annual burden of TBI has been estimated at over $\$ 60$ billion. ${ }^{5}$ Globally, the incidence is increasing, and TBI resulting from blast injuries is being increasingly recognized in military personnel returning from the Middle East conflicts. In the Western world, the epidemiology of TBI is slowly changing with a relative increase in middle-aged and elderly patients injured by falls, resulting typically in contusional brain damage. ${ }^{4}$ Contusional brain injury is different from diffuse axonal injury, with a much larger component of inflammatory response, and this is often characterized by lesion progression. Approximately 25 to $45 \%$ of cerebral contusions will enlarge significantly, ${ }^{6,7}$ and even higher occurrences are reported if the initial computed tomographic scan is performed within $2 \mathrm{~h}$ of injury. ${ }^{8}$ The more frequent use of anticoagulant medication and platelet aggregation inhibitors in older patients may further increase the risk of lesion progression. The frequent progression of contusive brain injury indicates that this may constitute a subpopulation of TBI more likely to benefit from neuroprotective agents by limiting processes involved in secondary brain damage. Other mechanisms, and consequently different approaches may be more relevant in patients with diffuse axonal injury, and we emphasize that neuroprotection in a more broad sense also includes strategies and therapies aimed at promoting regeneration or replacement of lost neuronal and glial cells, neuronal circuits, and stimulation of neuroplasticity.

The aim of this article is to review past and current experiences in clinical trials of TBIs, to discuss limitations and challenges that have been recognized, and to summarize current directions. The focus is on studies of patients with severe and moderate TBIs.

\section{CLINICAL TRIALS IN TBI: PAST EXPERIENCE}

The history of multicenter, randomized controlled trials of TBI really started in the mid-1980s. Major pillars of clinical research, such as the Glasgow coma scale, the Glasgow outcome scale and computed tomographic scanning were only introduced in the 1970s. A further boost toward trials resulted from advances in basic research with the identification of various neuroprotective agents. Prior to 1980 , the majority of trials that were reported consisted of single-center studies with evaluation of treatment results that often used historical controls. In this period, a particular interest focused on the efficacy of steroids. These trials were primarily initiated by investigators from scientific interest; in contrast, multicenter trials on neuroprotective agents from the mid1980s on were largely initiated by pharmaceutical companies. The collaboration between investigators and pharmaceutical companies proved beneficial to both sides; investigators contributed disease-specific expertise, and the participation in trials greatly facilitated international contact and collaboration. Indirectly this has probably led to improved quality of care.

We conducted a systematic literature search of TBI clinical trials for the period of 1980 to 2009. We included studies meeting the following criteria:

- Prospective, parallel groups, phase III RCT with random assignment to either a new medication/intervention or placebo/best intervention available

- Patients with closed, moderate to severe TBI (e.g., Glagow coma score $\leq 12)$

- Acute presentations $(<24 \mathrm{~h}$ between injury and treatment)

- Patients with primary outcomes expressed as a Glasgow outcome score $\geq 3$ months

- Reports in the English language.

We excluded the following criteria:

- Phase II RCTs

- Studies focusing on mild TBIs or on chronic TBI treatments (e.g., rehabilitations)

- Studies on pediatric TBIs

- Studies using a different primary outcome measure than the Glasgow outcome score.

We selected studies focusing on adults ( $>15$ years) and studies that included at least 100 patients (minimum, 50 per arm). In total, 27 studies met these criteria. Collectively, we were aware of another 6 unpublished, large phase III TBI trials from which we had sufficient knowledge to present details. Therefore, these studies were added to the selection, resulting in a total of 33 studies. A complete overview of the studies is presented in Table 1. This overview permits a number of interesting observations as follows.

First, there is a peak incidence of trial initiations in the mid-1990s, with a sharp decline in the period from 2000 
Table 1. Overview

\begin{tabular}{|c|c|c|c|c|c|c|c|}
\hline Publication (Funding) & $\begin{array}{l}\text { Agent/Intervention } \\
\text { (Mechanism) }\end{array}$ & Centers & Study Population & No. & $\begin{array}{l}\text { Year of } \\
\text { Study }\end{array}$ & Status & Results \\
\hline $\begin{array}{l}\text { Braakman et al., }{ }^{26} 1983 \\
\text { (inv. initiated) }\end{array}$ & $\begin{array}{l}\text { High dose dexamethasone } \\
\text { (various processes) }\end{array}$ & 2 & $\begin{array}{l}\text { Comatose patients after } \\
\text { nonmissile TBI }\end{array}$ & 161 & $1978-1981$ & Completed & No sign. Tx. effect \\
\hline Dearden et al., ${ }^{27} 1986$ & $\begin{array}{l}\text { Dexamethasone (various } \\
\text { processes) }\end{array}$ & 1 & Severe head injury & 130 & $1980-1983$ & Completed & No sign. Tx. effect \\
\hline $\begin{array}{l}\text { Grumme et al., } \\
\text { initiated) }\end{array}$ & $\begin{array}{l}\text { Triamcinolone (various } \\
\text { processes) }\end{array}$ & 9 & $\begin{array}{l}\text { Severe head injury, not } \\
\text { further defined }\end{array}$ & 396 & 1985-1990 & Completed & No sign. Tx. effect \\
\hline $\begin{array}{l}\text { Bailey et al., }{ }^{18} 1991 \\
\text { (Bayer - HIT I) }\end{array}$ & $\begin{array}{l}\text { Nimodipine } \\
\text { (Ca- mediated damage) }\end{array}$ & 6 & $\begin{array}{l}\text { Not obeying } \\
\text { commands }\end{array}$ & 351 & 1987-1989 & Completed & No sign. Tx. effect \\
\hline $\begin{array}{l}\text { Eur study group, }{ }^{19} 1994 \\
\text { (Baver - HIT II) }\end{array}$ & $\begin{array}{l}\text { Nimodipine (Ca- } \\
\text { mediated damage) }\end{array}$ & 21 & $\begin{array}{l}\text { Not obeying } \\
\text { commands }\end{array}$ & 852 & 1989-1991 & Completed & $\begin{array}{l}\text { No significant effect in } \\
\text { overall population }\end{array}$ \\
\hline $\begin{array}{l}\text { Rockswold et al., }{ }^{28} 1992 \\
\text { (Inv. initiated) }\end{array}$ & $\begin{array}{l}\text { Hyperbaric oxygen } \\
\text { (cerebral ischemia) }\end{array}$ & 1 & $\mathrm{GCS} \leq 9$ & 168 & 1983-1989 & Completed & Reduced mortality \\
\hline Wolf et al., ${ }^{29} 1993$ (NIH: & Tromethamine (THAM) & 2 & GCS $\leq 8$ & 149 & 1988-1989 & Completed & No overall treatment effect \\
\hline $\begin{array}{l}\text { Gaab et al., } \\
\text { initiated) }\end{array}$ & $\begin{array}{l}\text { Dexamethasone (various } \\
\text { processes) }\end{array}$ & 10 & $\mathrm{GCS} \leq 13$ & 300 & 1986-1989 & Completed & No sign. Tx. effect \\
\hline $\begin{array}{l}\text { Unpublished: tiriliazad- } \\
\text { domestic (Upjohn) }\end{array}$ & $\begin{array}{l}\text { Tirilazad (lipid } \\
\text { peroxidation) }\end{array}$ & 36 & $\begin{array}{l}\text { GCS } \leq 8: 72 \% \\
\text { GCS } 9-12: 28 \%\end{array}$ & 1155 & 1991-1994 & Terminated & No sign. Tx. effect reported \\
\hline $\begin{array}{l}\text { Marshall et al., } 1998 \\
\text { Tirilazad-International } \\
\text { (Upjohn) }\end{array}$ & $\begin{array}{r}\text { Tirilazad (lipid } \\
\text { peroxidation) }\end{array}$ & 50 & $\begin{array}{l}\text { GCS } \leq 8: 85 \% \\
\text { GCS } 9-12: 15 \%\end{array}$ & 1120 & 1992-1994 & Completed & No sign. Tx. effect \\
\hline $\begin{array}{l}\text { Young et al., }{ }^{21} 1996 \\
\text { (Sanofi-Winthrop) }\end{array}$ & $\begin{array}{l}\text { PEGSOD (free radical } \\
\text { damage) }\end{array}$ & 29 & $\mathrm{GCS} \leq 8$ & 1562 & 1993-1995 & Completed & No sign. Tx. effect \\
\hline Unplublished (SyntheLabo) & $\begin{array}{l}\text { Eliprodil (glutamate } \\
\text { exitotoxicity) }\end{array}$ & $20+$ & GCS 4-8 & 452 & 1993-1995 & Completed & No sign. Tx. effect \\
\hline $\begin{array}{l}\text { Harders et al., }{ }^{9} 1996 \\
\text { (Bayer - HIT III) }\end{array}$ & $\begin{array}{l}\text { Nimodipine (Ca- } \\
\text { mediated damage) }\end{array}$ & 21 & $\mathrm{tSAH}$ & 123 & 1994 & Completed & $\begin{array}{l}\text { Significant reduction in } \\
\text { unfavorable outcome }\end{array}$ \\
\hline $\begin{array}{l}\text { Robertson et al., } 1999 \\
\text { (Inv. initiated, NIH } \\
\text { NS27616) }\end{array}$ & $\begin{array}{l}\text { CBF vs. ICP directed } \\
\text { management (cerebral } \\
\text { ischemia) }\end{array}$ & 1 & Motor score $\leq 5$ & 189 & 1994-1997 & Completed & $\begin{array}{l}\text { No difference in neurologic } \\
\text { outcome. Decrease in } \\
\text { episodes of jugular } \\
\text { desaturation }\end{array}$ \\
\hline $\begin{array}{l}\text { Morris et al., }{ }^{33} 1999 \\
\text { (Ciba-Geigy, Novartis) }\end{array}$ & $\begin{array}{l}\text { Selfotel (glutamate } \\
\text { exitotoxicity) }\end{array}$ & 95 & GCS 4-8 & 693 & 1994-1996 & Terminated & No sign. Tx. effect \\
\hline $\begin{array}{l}\text { Clifton et al., } 2001 \text { (Inv. } \\
\text { initiated, NIH NS 32786) }\end{array}$ & $\begin{array}{l}\text { Hypothermia - NABIS } \\
\text { (various processes) }\end{array}$ & 11 & $\begin{array}{l}\text { GCS } 3-8 \text { Motor score } \\
1-5\end{array}$ & 392 & 1994-1998 & Halted & $\begin{array}{l}\text { No effects on outcome. } \\
\text { Reduced incidence of } \\
\text { ICP }>30\end{array}$ \\
\hline $\begin{array}{l}\text { Unpublished (Sandoz, } \\
\text { Novartis) }\end{array}$ & $\begin{array}{l}\text { D-CPP-ene - Saphir } \\
\quad \text { (glutamate } \\
\text { exitotoxicity) }\end{array}$ & 51 & $\begin{array}{l}\text { Not obeying } \\
\text { commands, } \geq \text { one } \\
\text { reactive pupil }\end{array}$ & 924 & 1995-1997 & Completed & No sign. Tx. effect \\
\hline $\begin{array}{l}\text { Marmarou et al., }{ }^{22} 1999 \\
\text { (SmithKlineBeecham/ } \\
\text { Cortech Inc.) }\end{array}$ & $\begin{array}{l}\text { Bradycor/CP- } \\
0127 \text { (bradykinine } \\
\text { antagonist) }\end{array}$ & 31 & GCS 3-8 & 139 & 1996 & Terminated & $\begin{array}{l}12 \% \text { improvement in } \\
\text { favorable outcome } \\
(p=0.26)\end{array}$ \\
\hline
\end{tabular}


Table 1. Continued

\begin{tabular}{|c|c|c|c|c|c|c|c|}
\hline Publication (Funding) & $\begin{array}{l}\text { Agent/Intervention } \\
\text { (Mechanism) }\end{array}$ & Centers & Study Population & No. & $\begin{array}{l}\text { Year of } \\
\text { Study }\end{array}$ & Status & Results \\
\hline $\begin{array}{l}\text { Unpublished (Cambridge } \\
\text { Neuroscience) }\end{array}$ & $\begin{array}{l}\text { Cerestat/aptiganel } \\
\text { (glutamate } \\
\text { exitotoxicity) }\end{array}$ & 38 & $\begin{array}{l}\text { GCS } 4-8 \\
\text { GCS } 3 \text { if pupils } \\
\text { reactive }\end{array}$ & 532 & 1996-1997 & Terminated & No sign. Tx. effect \\
\hline Unpublished (Parke Davis) & $\begin{array}{l}\text { SNX-111 (Glutamate } \\
\text { exitotoxicity) }\end{array}$ & ? (multi-center) & GCS 4-8 & 237 & 1997-1998 & Terminated & Higher mortality \\
\hline $\begin{array}{l}\text { Unpublished (Bayer HIT } \\
\text { IV) }\end{array}$ & $\begin{array}{l}\text { Nimodipine (Ca- } \\
\text { mediated damage) }\end{array}$ & 36 & $\mathrm{GCS}<15+\mathrm{tSAH}$ & 592 & 1997-1999 & Completed & No significant effect \\
\hline $\begin{array}{l}\text { Yurkewicz et al., }{ }^{23} 2005 \\
\text { (Pfizer) }\end{array}$ & $\begin{array}{l}\text { Traxoprodil (CP-101606) } \\
\text { (Ca- channel blocker) }\end{array}$ & ? (multi-center) & GCS 4-8 & 404 & 1998-2001 & Completed & $\begin{array}{l}\text { Higher mortality, } \\
\text { nonsignificant effect }\end{array}$ \\
\hline $\begin{array}{l}\text { Cooper et al., }{ }^{34} 2004 \text { (inv. } \\
\text { initiated, MRC-Aus: } \\
\text { 124330) }\end{array}$ & $\begin{array}{l}\text { Hypertonic saline } \\
\text { (hypovolemia) }\end{array}$ & 12 & $\mathrm{GCS} \leq 8$ & 229 & 1998-2002 & Completed & No sign. Tx. effect \\
\hline $\begin{array}{l}\text { Temkin et al., }{ }^{35} 2007 \text { (inv. } \\
\text { initiated, NIH: NS 19643) }\end{array}$ & $\begin{array}{l}\text { Magnesium sulfate } \\
\text { (multiple mechanisms) }\end{array}$ & 1 & $\mathrm{GCS} \leq 12$ & 499 & 1998-2004 & Completed & $\begin{array}{l}\text { Poorer outcome in treated } \\
\text { group }\end{array}$ \\
\hline $\begin{array}{l}\text { Maas et al., }{ }^{17} 2006 \\
\text { (Pharmos Corp.) }\end{array}$ & $\begin{array}{l}\text { Dexanabinol (multiple } \\
\text { processes) }\end{array}$ & 86 & $\begin{array}{l}\text { Motor score } 2-5+\mathrm{CT} \\
\text { abnormalities }\end{array}$ & 861 & 2000-2004 & Completed & No sign. Tx. effect \\
\hline $\begin{array}{l}\text { Edwards et al., }{ }^{1 \dagger} 2005 \\
\text { (MRC UK) }\end{array}$ & $\begin{array}{l}\text { Methylprednisolone } \\
\text { (multiple mechanisms) }\end{array}$ & 239 & $\mathrm{GCS} \leq 14$ & 10008 & 1999-2004 & Terminated & $\begin{array}{l}\text { Higher mortality in Tx. } \\
\text { group }(p=0.001)\end{array}$ \\
\hline $\begin{array}{l}\text { Cruz et al., }{ }^{36 *} 2001 \\
\text { (Investigator initiated) }\end{array}$ & $\begin{array}{l}\text { High-dose mannitol } \\
\text { (raised ICP) }\end{array}$ & 1 & ASDH & 178 & 1997-2000 & Completed & $\begin{array}{l}\text { Significant better outcome } \\
\qquad(p<0.01)\end{array}$ \\
\hline $\begin{array}{l}\text { Cruz et al., }{ }^{37} * 2002 \\
\text { (Investigator initiated) }\end{array}$ & $\begin{array}{l}\text { High-dose mannitol } \\
\text { (raised ICP) }\end{array}$ & 1 & $\begin{array}{l}\text { Temporal lobe } \\
\text { hemorrhage with } \\
\text { abnormal pupils }\end{array}$ & 141 & 1997-2001 & Completed & Significant treatment effect \\
\hline $\begin{array}{l}\text { Zhi et al., }{ }^{12} 2003 \\
\text { (Investigator initiated) }\end{array}$ & $\begin{array}{l}\text { Mild hypothermia } \\
\text { (various processes) }\end{array}$ & 1 & $\mathrm{GCS} \leq 8$ & 396 & 1997-2001 & Completed & $\begin{array}{l}\text { Reduction of mortality and } \\
\text { improved outcome }\end{array}$ \\
\hline $\begin{array}{l}\text { Lu et al., }{ }^{13} 2003 \\
\text { (Investigator initiated) }\end{array}$ & $\begin{array}{l}\text { Decompr. craniectomy } \\
\text { (raised ICP) }\end{array}$ & 1 & $\mathrm{GCS} \leq 8$ & 230 & 1998-2001 & Completed & $\begin{array}{l}\text { Significant reduction of } \\
\text { mortality }\end{array}$ \\
\hline $\begin{array}{l}\text { Jiang et al., }{ }^{14} 2005 \\
\text { (Investigator initiated) }\end{array}$ & $\begin{array}{l}\text { Standard trauma } \\
\text { craniectomy vs. limited } \\
\text { craniectomy (raised } \\
\text { ICP) }\end{array}$ & 5 & $\begin{array}{l}\text { GCS } \leq 8+\text { refractory } \\
\text { intracranial } \\
\text { hypertension }\end{array}$ & 468 & 1998-2001 & Completed & $\begin{array}{l}\text { Better outcome with large } \\
\text { craniectomy }\end{array}$ \\
\hline $\begin{array}{l}\text { Jiang et al., }{ }^{15} 2006 \\
\text { (Investigator initiated) }\end{array}$ & $\begin{array}{l}\text { Long-term mild } \\
\text { hypothermia (multiple } \\
\text { mechanisms) }\end{array}$ & 3 & $\mathrm{GCS} \leq 8$ & 215 & 2000-2003 & Completed & $\begin{array}{l}\text { 5-day mild hypothermia is } \\
\text { more efficacious than } \\
\text { 2-day short term }\end{array}$ \\
\hline $\begin{array}{l}\text { Xiao et al., }{ }^{10} 2008 \\
\text { (Investigator initiated) }\end{array}$ & $\begin{array}{l}\text { Progesterone (multiple } \\
\text { mechanisms) }\end{array}$ & 1 & $\mathrm{GCS} \leq 8$ & 159 & 2004-2007 & Completed & $\begin{array}{l}\text { More favorable outcome in } \\
\text { Tx. group }(p=0.048)\end{array}$ \\
\hline
\end{tabular}

ASDH = acute subdural hematoma; $\mathrm{CBF}=$ cerebral blood flow; $\mathrm{CT}=$ computed tomography; GCS = Glasgow coma score; HIT $=$ Head Injury Trial; ICP = intracranial pressure; NABIS = National

Acute Brain Injury Study; PEGSOD $=$ polyethylene glycol-conjugated bovine superoxide dismutase; Tx. = treatment.
$*$ The studies reported by Cruz et al. ${ }^{36,37,39}$ have been subjected to severe criticism, and the reliability and validity of the results have been questioned. 
to 2004. This holds true for both studies with neuroprotective agents and studies using therapeutic strategies (e.g., hypothermia or decompressive craniectomy). We recognize that studies initiated in the latter years may not all have been published yet, and we are aware of four phase III studies on therapeutic strategies (two on decompressive craniectomy, one on hypothermia, and one on the antifibrinolytic agent tranexamic acid [Clinical Randomization of an Antifibrinolytic in Significant Hemorrhage (CRASH 2)]), but of only one trial with a neuroprotective agent (recombinant human erythropoietin [rhEPO]) that is currently enrolling or was recently completed (Table 2). FIG. 1 summarizes the number of phase III RCTs initiated per 5-year period in moderate and severe TBIs since 1980. The decline in studies on neuroprotective agents does not seem to be caused by a lack of new agents with great potential, but it is more likely due to the difficulties experienced in previous trials combined with the high costs.

Second, most studies reported a significant treatment effect concerning those using a therapeutic strategy as an investigational modality. Seven of 10 studies on therapeutic strategies demonstrated statistical significance versus only 3 of 23 on neuroprotective agents (Table 3 ). The three studies on neuroprotective agents that show a significant treatment effect are the Head Injury Trial (HIT) III nimodipine study, ${ }^{9}$ the study reported by Xiao et $\mathrm{al}^{10}$ on progesterone (both of which show beneficial effects), and the CRASH study, ${ }^{11}$ which demonstrated higher mortality in the steroid-treated patients. These three trials had features that distinguished them from the traditional design of TBI trials. The HIT III study targeted a subgroup of the overall population, which only included patients with traumatic subarachnoid hemorrhage. The progesterone study reported by Xiao et al. ${ }^{10}$ concerned a single-center study. The CRASH trials represented the only "mega trial" conducted in the field of TBI.

Third, we noted that six of the nine single-center studies showed a significant treatment effect versus 4 of the 24 multicenter studies (Table 4).

Fourth, a certain shift can be noted during the past 5 to 10 years of studies from the Western hemisphere toward the Far East. These primarily concern investigator-initiated studies, which we find extremely encouraging, but we also note an increasing interest of pharmaceutical companies for moving trials to include centers in the Far East. This shift is motivated by both higher patient recruitment and lower costs. Further collaboration is highly recommended, but at the same time we wish to introduce a word of caution that it is yet uncertain as to how the results obtained in a different setting may translate into a more global perspective. This is important, for example, because of various trials conducted in mainland China that have shown beneficial effects of decompressive craniectomy, hypothermia, and progesterone. ${ }^{10,12-15}$ These were all well-designed, high-quality studies. However, it is conceivable that differences may exist in referral policies, potential for selection bias, access to health care, acute and post-acute treatments, and outcome. We consider it a priority to investigate these issues in a comparative, observational study.

Two other issues deserve special consideration: 1) the number of unpublished studies and 2) the reasons why some studies were prematurely ended. In total, six studies included in the overview have not been published (tirilazad-domestic, Eliprodil, Saphir, Cerestat, Parke-Davis and HIT IV). These were all large, pivotal trials that we could include in the overview due to our knowledge of the field. However, there may be more "negative" trials to which we are not aware, particularly single-center studies. It is regrettable that these studies have not yet been published, as we consider it a moral obligation to patients and relatives who consented in participating and to the community in general to publish these results, even if a trial does not yield a positive result.

In total, seven trials were prematurely terminated. The National Acute Brain Injury Study (NABIS) hypothermia trial was originally initiated with the goal of enrolling 500 patients, but it was prematurely halted after enrollment of 392 patients after an unscheduled futility analysis showing that the likelihood for demonstrating benefit on continuation was low. The tirilazad domestic trial was prematurely halted after enrollment of 1191 of the planned 1212 patients $(98.3 \%)$ on the recommendation of the data safety monitoring committee having demonstrated a significant difference in mortality between the treatment groups. A more detailed subsequent analysis found that this difference in mortality could be explained by differences in baseline characteristics; however, because the target enrollment had nearly been reached, the decision was made to terminate the study. The Selfotel trials (United States and international) were stopped after an enrollment of 693 patients, because of concerns of the safety and monitoring committee regarding an increased number of deaths and severe brainrelated adverse events that had occurred in two contemporary trials in stroke. Such adverse events were not noted in the TBI trials, but as analysis indicated a low likelihood of demonstrating benefit on pursuing the trial to completion, the decision was made to definitively stop the enrollment. The Cerestat trial originally aimed to enroll 700 patients, but was halted after enrollment of 532 patients after a planned interim analysis conducted on the first 340 patients. This decision was also made against the background of concern about the effects of the agent in patients with stroke. The Parke Davis study on SNX-111 was halted prematurely when the data safety monitoring board observed a $10 \%$ increase of 
Table 2. Recently Completed, Ongoing, and Expected Studies

\begin{tabular}{|c|c|c|c|c|c|c|c|}
\hline Funding Sponsoring & Study + Agent & Mechanism Targeted & Type Study & $\begin{array}{c}\text { Study } \\
\text { Population }\end{array}$ & Target No. & Start Year & Status \\
\hline $\begin{array}{l}\text { Investigator initiated } \\
\text { (Zhejiang and Hangzhou } \\
\text { Health Department, } \\
\text { China) }\end{array}$ & $\begin{array}{l}\text { Decompressive } \\
\text { craniectomy }\end{array}$ & Raised ICP & Phase II & $\mathrm{GCS} \leq 8$ & 80 & 2003 & Completed Dec 2008 \\
\hline NIH-NINDS & Cyclosporin A & $\begin{array}{l}\text { Mitochondrial } \\
\text { dysfunction }\end{array}$ & Phase II safety & GCS 3-8 & 50 & 2003 & $\begin{array}{l}\text { Completed (Mazzeo } \\
\text { et al. }{ }^{38} 2009 \text { ) }\end{array}$ \\
\hline Biotherapeutics & Oxycyte (oxygen carrier) & $\begin{array}{l}\text { Increase cerebral } \\
\text { oxygenation }\end{array}$ & Phase II & $\mathrm{GCS} \leq 9$ & 8 & 2005 & Completed Jan 2008 \\
\hline Key Neurotek A.G. & KN 38-7271 & $\begin{array}{l}\text { Cannabinoid receptor } \\
\text { agonist }\end{array}$ & Phase II a & Severe TBI & 97 & 2006 & Completed Dec 2008 \\
\hline $\begin{array}{l}\text { Investigator initiated } \\
\text { (Department of Health, } \\
\text { Taipei City Government, } \\
\text { Taiwan) }\end{array}$ & $\begin{array}{l}\text { Multiple cerebral } \\
\text { monitoring }\end{array}$ & Multiple & Phase II b & GCS 3-8 & 320 & 2006 & Ongoing \\
\hline Xytis Pharmaceuticals & XY 2405 & $\begin{array}{l}\text { Bradykinine (beta } 2 \\
\text { receptor) antagonist }\end{array}$ & Phase II & GCS $\leq 12$ & 400 & 2007 & $\begin{array}{l}\text { Stopped early June } \\
2008\end{array}$ \\
\hline $\begin{array}{l}\text { Investigator initiated } \\
\text { (Cambridge University } \\
\text { Hospitals NHS } \\
\text { Foundation Trust, UK) }\end{array}$ & $\begin{array}{l}\text { Interleukin-1 receptor } \\
\text { antagonist }\end{array}$ & $\begin{array}{l}\text { Inflammatory } \\
\text { response }\end{array}$ & Phase II safety & GCS $\leq 8$ & 26 & 2008 & Ongoing \\
\hline Biotherapeutics & Oxycyte (oxygen carrier) & Cerebral ischaemia & Phase II safety & Severe TBI & 128 & July 2009 & Ongoing \\
\hline Solvay Pharmaceuticals & $\begin{array}{l}\text { SLV334 (ECE/NEP } \\
\text { inhibitor) preventing } \\
\text { formation of the } \\
\text { vasoconstrictor ET-1 }\end{array}$ & $\begin{array}{l}\text { Cerebral } \\
\text { vasoconstriction; } \\
\text { atrial natriuretic } \\
\text { peptide }\end{array}$ & Phase II & $\begin{array}{c}\text { Moderate and } \\
\text { severe TBI }\end{array}$ & 72 & 2009 & Ongoing \\
\hline Neuren Pharmaceuticals & NNZ 2566 & Multiple & $\begin{array}{l}\text { Phase II dose } \\
\text { escalation }\end{array}$ & $?$ & $?$ & $2009 ?$ & $\begin{array}{l}\text { Expected to start } \\
\text { October }\end{array}$ \\
\hline Vasopharm & VAS 203 & Nitric oxyde synthesis & Phase II & Severe & $?$ & $?$ & Expected \\
\hline $\begin{array}{l}\text { Investigator initiated (MRC } \\
\text { Australia) }\end{array}$ & $\begin{array}{l}\text { Decompressive } \\
\text { craniectomy (DECRA) }\end{array}$ & Raised ICP & Phase III & $\begin{array}{l}\text { Severe TBI: ICP } \\
>20 \mathrm{mmHg} \\
\text { for } 15 \mathrm{~min} \text { in } \\
1 \mathrm{~h} \text { refractory } \\
\text { to med. } \\
\text { measures }\end{array}$ & 165 & 2004 & Ongoing \\
\hline $\begin{array}{l}\text { Investigator intiated (NIH- } \\
\text { NINDS) }\end{array}$ & $\begin{array}{l}\text { NABIS: H IIR } \\
\text { Hypothermia }\end{array}$ & Multiple & Phase III & GCS $3-8$ & 240 & 2005 & Stopped \\
\hline $\begin{array}{l}\text { Investigator initiated (MRC } \\
\text { UK) }\end{array}$ & $\begin{array}{l}\text { RescueICP } \\
\text { (decompressive } \\
\text { craniectomy) }\end{array}$ & Raised ICP & Phase III & $\begin{array}{l}\mathrm{ICP}>25 \mathrm{mmHg} \\
\text { for } 1 \mathrm{~h} \\
\text { refractory to } \\
\text { med. measures }\end{array}$ & 500 & 2005 & Ongoing \\
\hline NIH-NINDS & $\begin{array}{l}\text { Rrecombinant Human } \\
\text { Erythropoetin (rhEPO) }\end{array}$ & Multiple & Phase III & GCS motor $\leq 5$ & 200 & 2006 & Ongoing \\
\hline
\end{tabular}


mortality in treated patients; the occurrence of hypotension as a complication of the use of calcium channel blockers was also noted in the study. The Bradycor trial was designed to enroll 160 evaluable patients, but was stopped after 139 patients were enrolled, and after the results of animal toxicology studies conducted during the course of the trial; these results were largely inconclusive after repeat studies, and the decision to terminate the trial was perhaps all the more regrettable as a strong trend toward benefit was noted on the Glasgow outcome score at 6 months (12\% improvement) and was supported by positive trends seen in intracranial pressure, therapy intensity level, and neuropsychological tests. The CRASH mega trial was originally aimed to include a total of approximately 20,000 patients, but was stopped in May 2004 after enrollment of 10,008 patients because of an excess in early mortality (day 14). These observations demonstrate that there are many internal and external factors that influence the conduct of TBI trials. In three cases, the reasons were safety concerns within the trial. In three cases, external factors included experience in simultaneously conducted stroke trials, the results in preclinical studies, and in only one instance (ie, the NABIS hypothermia trial) this resulted from the futility analysis. Indirectly, however, aspects of futility also probably influenced the decision making in tirilazad, Selfotel, and Cerestat.

The observation that the majority of studies showing efficacy of the interventional therapy concerns singlecenter studies, while the overwhelming majority of multicenter studies failed to demonstrate effect is of interest and raises the question as to whether this may simply reflect publication bias or whether the center effects may be a factor confounding chances of demonstrating efficacy. Considerable between center differences in 6-month unfavorable outcome have been reported in the NABIS hypothermia trial. ${ }^{16}$ Significant differences in mortality were also found between high- and low-enrolling centers in one of the more recent trials in TBI, investigating the efficacy of dexanabinol. ${ }^{17}$ The International Mission on Prognosis and Clinical Trial Design in TBI (IMPACT) studies have further shown a 3.3-fold difference after correction for random variation in the odds of having an unfavorable outcome between centers $(p<0.001)$, which was not explained by patient characteristics (Lingsma et al., submitted for publication). These data illustrate some of the complexities involved in multicenter trials. The advantage of multicenter trials in comparison with single-center studies is enhanced generalizability. Two different approaches may be pursued to minimize variability in choice and sequence of basic therapeutic approaches: 1) rigorous standardization of treatment and 2) recruiting so many patients into a mega trial that variability is of less concern. An example of the latter approach is the CRASH study. However, the 


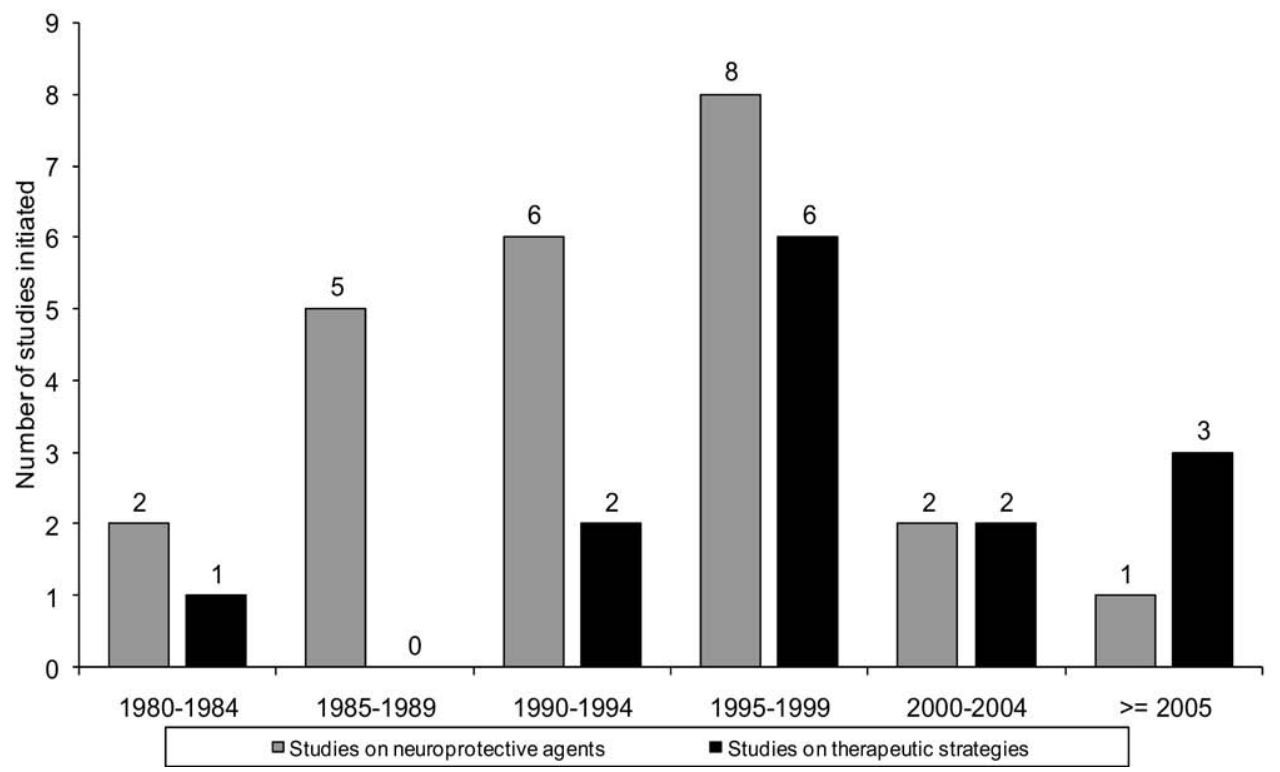

FIG. 1. Numbers of initiated randomized controlled trials on moderate to severe traumatic brain injury per 5-year time periods. Trials were grouped by studies on neuroprotective agents and studies on therapeutic strategies.

relative merits of these two contrasting approaches needs to be further determined.

\section{RECENTLY COMPLETED, ONGOING, AND EXPECTED STUDIES}

General information on "new" and recently completed trials can be found on the following websites: see www. clinicaltrials.gov (U.S. National Institutes of Health trial registry) and www.controlled-trials.com (nongovernmental registry initiated by Springer Science and Business Media supervised by an international advisory group). Central registration of clinical trials via these registries or the Eudra clinical trials database in the European Union has served to promote quality in the design and reporting of clinical trials. Data from the European Medicines Agency (EMEA) registry (EudraCT) are not yet publicly available, but this is anticipated for 2010 . Regulatory agencies consider formal registration of the trial mandatory when considering drug approval, and journal editors may refuse publication of trial results if the trial has not been registered prior to initiation. An overview of recently completed, ongoing, and expected studies is presented in Table 2. Much of this knowledge

Table 3. Trial Results: Differentiated for Type of Investigational Therapy

\begin{tabular}{lcc}
\hline \multicolumn{1}{c}{$\begin{array}{c}\text { Interventional } \\
\text { Therapy }\end{array}$} & $\begin{array}{c}\text { Significant } \\
\text { Effect }\end{array}$ & $\begin{array}{c}\text { No Significant } \\
\text { Effect }\end{array}$ \\
\hline $\begin{array}{l}\text { Neuroprotective agent } \\
\text { Therapeutic strategy }\end{array}$ & 3 & 20 \\
\hline
\end{tabular}

is now in the public domain by virtue of the central trial registries.

This overview indicates that many of the studies concern early stage clinical development. Currently, we believe that there are five phase III trials that are ongoing (four on therapeutic strategies and one on the neuroprotective agent recombinant human erythropoietin). A phase III trial on hypothermia is expected to start soon, supported by the European Society for Intensive Care Medicine. Preparations for a further two trials on progesterone are ongoing, and it is expected that these studies will be open for enrollment early in 2010 .

Compared with the past decade, the number of studies on neuroprotective agents being taken forward into efficacy-oriented studies is dismal. We do not consider this due to lack of potential agents, but rather due to reluctance to embark on a high-risk venture, which is moreover extremely costly. In times of "trial crisis," there is believed to be a clear need for improved trial methodology to decrease the risks, and we strongly believe that if we wish to continue developing the field of neuroprotection in the clinical situation, attempts should be made to reduce costs. In particular, the substantial overhead costs often imposed in academic institutes is concerning.

Table 4. Trial Results: Single versus Multicenter Trials

\begin{tabular}{lcc}
\hline \multicolumn{1}{c}{ Type of Study } & $\begin{array}{c}\text { Significant } \\
\text { Effect }\end{array}$ & $\begin{array}{c}\text { No Significant } \\
\text { Effect }\end{array}$ \\
\hline Single-center trial & 6 & 3 \\
Multicenter trial & 4 & 20 \\
\hline
\end{tabular}




\section{Reappraisal of clinical trial methodology in TBI}

Overall, the results of the phase III trials on neuroprotective agents have been disappointing. These disappointing results have stimulated a critical reappraisal of conditional requirements before starting clinical trials with new interventional therapies and using the methodology of trial design and analysis. The reasons that previous trials have not shown convincing benefit reflect a number of factors, ranging from preclinical investigations, through problems in translating results from experimental studies to clinical practice, to the clinical situation in which it is uncertain whether the pathophysiologic mechanisms targeted are indeed active in the patients studied, and if so, at what time after injury. Experimental studies should be robust, preferably showing benefit in more than one model, and in more than one species, with effects on both mechanistic and behavioural endpoints. To what extent time windows determined in the experimental situation may be translated to clinical practice still remains a point of concern. Requirements postulated for successful phase II TBI trials include the following:

- Mechanism demonstrated in animal models

- Drug/agent reverses damage in animal models

- Mechanism shown to be active in human TBIs

- Neuroprotective agent that passes the brain barrier

- Safety/tolerability in humans with TBIs

- Drug-sensitive endpoints

Phase II trails are aimed at safety, and may include dose-escalation studies and, at best, may fulfill requirements for proof of concept by demonstrating efficacy on a mechanistic endpoint. However, in general, clinical efficacy and even indications thereof may not be expected from phase II TBI trials.

In most efficacy-oriented TBI trials (phase IIb or phase III studies), the hypothesis was to increase the absolute proportion of patients with a favorable outcome by at least $10 \%$. Such an effect may not have been proven at this predetermined level, but conversely neither has inefficacy been proven. In fact, many trials demonstrate some increase in favorable outcome, albeit nonsignificant in treated patients. For example, the HIT I trial on nimodipine showed an $8 \%$ relative improvement ${ }^{18}$ and the HIT II trial a $4 \%$ absolute improvement in favorable outcome in treated patients. ${ }^{19}$ In the triamcinolone trial, a 5\% increase in good recovery was observed in patients on active treatment. ${ }^{20}$ In the polyethylene glycol-conjugated bovine superoxide dismutase (PEGSOD) trial, there was a 9\% improvement in favorable outcome noted. ${ }^{21}$ In the Bradycor trial there was a $12 \%$ improvement. $^{22}$ The Pfizer study had a decrease of mortality of $7 \%$ and an increase in favorable outcome in the treated group. ${ }^{23}$ Therefore, it would appear that at least some trials show an indication of efficacy, and this may be interpreted as further evidence in support of the concept that TBI trials have been underpowered. Other factors, such as confounding effects of heterogeneity of TBI populations, overly optimistic expectations, and insensitive methodology have also contributed to the difficulties experienced in demonstrating benefit of investigational treatments. In comparison with other fields of medicine, efficacy-oriented clinical trials in TBI pose complicated methodological challenges. These methodological challenges are particularly related to three important factors: 1) the great heterogeneity of TBI populations, 2) the lack of relevant mechanistic early endpoints, and 3) the insensitivity of more global outcome measures. The consequences of heterogeneity in TBI populations from the perspective of trial design and analysis and approaches for dealing with this heterogeneity are the main focus of studies conducted by the IMPACT investigators. Results from these studies have shown that the statistical power in TBI trials may be increased by as much as $50 \%$ by utilizing more efficient approaches to the analysis. Recommendations and results originating from the IMPACT work are summarized in a dedicated article in this issue. ${ }^{24}$

The IMPACT studies were conducted on individual patient data from eight RCTs and three observational studies. ${ }^{25}$ Relevant parameters from the individual studies were merged into a large dataset, forming a "culture medium" for exploring concepts for improving the design of clinical trials in TBI. Merging the individual patient data into a common format proved to be even more formidable of a task than initially anticipated, and it involved more than 10-person years of work. The TBI datasets demonstrated almost as much heterogeneity as patient populations concerning coding of variables and data storage; furthermore, most datasets were characterized by general lack of detailed documentation. This experience highlighted the need for standardization of coding and data storage formats in TBI studies, and helped stimulate an international and inter-agency initiative to develop recommendations for "common data elements" for TBI studies.

\section{Standardization of data collection: common data elements}

The initial steps toward development of standardization of data collection in TBIs were integrated into a much larger inter-agency initiative toward "an integrated approach to research in psychological health and traumatic brain injury." This initiative, involving the National Institute of Neurological Disorders and Stroke (NINDS), the National Institute on Disability and Rehabilitation Research (NIDRR), the department of Veterans Affairs (VA), the Defense and Veterans Brain Injury 
Center (DVBIC), and the Defense Centers of Excellence (DCoE), included four working groups in the field of TBI addressing four domains: 1) demographics and clinical assessment, 2) biomarkers, 3) neuroimaging, and 4) outcome. Full results and recommendations of these working groups will be published in early 2010. The working group: "demographics and clinical assessment" (members included in appendix) focused on developing common data elements on all clinical and demographic variables in TBI studies. Specific aspects relating to biomarkers, neuroimaging, and outcome assessment, including recommendations for further development required to advance the field, were addressed by other working groups. The global aim was to develop recommendations on selection and coding of data elements for studies across the broad spectrum of TBI. The elements should be applicable to the entire spectrum on injury, both to milder and more severe injuries, to acute and long-term studies, and to studies including patients early after injury, but also to those enrolling patients at later time periods; elements should further be applicable to both civilian and military settings. Consistency was sought with the common data elements initiative of the U.S. National Institutes of Health, National Institute of Neurological Disorders and Stroke (see www.nindscommondataelements.org) initiated by John Marler who was vice director at the time with the aim to develop a core set of variables for use across the different fields of clinical neuroresearch.

The process for developing recommendations for common data elements was consensus driven, with multidisciplinary input from experts across a broad range of disciplines, covering the entire trauma chain from emergency medicine to rehabilitation and late outpatient care. Thus, a broad input was ensured. A general consensus on selection and coding of data elements was achieved, and templates were produced that summarized coding formats, motivation of choices, and recommendations for procedures. The data elements are contained in modules, which are grouped together in categories. For example, the data elements "age, gender, and race" are contained in the module "demographics" under the category "subject characteristics." It was further realized that the level of detail required in data collection may vary greatly with the design and aim of a specific study. Therefore, we developed three versions for coding data elements: 1) a basic version, 2) an advanced version, and 3) an extended format with the greatest level of detail in the extended version. The coding of these versions is such that in every case the more detailed coding can be collapsed into the basic version, thus facilitating comparison and meta-analysis of individual patient data between studies. The data elements and modules are intended as "building blocks" for designing a case report form. They can be used as "plug in" elements and are used multiple times in various sections of the case report form. For example, the module on the Glasgow coma scale (and pupils) may be recorded only on admission or also in pre-hospital, as well as daily, records during the acute care phase. Researchers can select and mix basic, advanced, and extended versions of the different data elements, according to the requirement of the study. We note that the data elements proposed are not all inclusive, and the option always remains open to include other elements. The complete package of common data elements, including the templates, are available from the author and will be posted on the website www. nindscommondataelements.org in early 2010. The data elements are currently presented in a "paper-based format." Work is ongoing to include the elements and modules in a web-based data entry format with pull-down menus and automated data checks. We emphasize that the current recommendations represent a beta version; we are in the process of incorporating feedback from a more international forum with the intent to make this a global initiative. We further note that some of the recommendations include innovative approaches, which require field testing and validation in clinical practice. Evaluating the applicability of the recommendations across various settings can best be accomplished by an observational study. The initiative to develop standard data elements in the field of TBI will facilitate comparison of research findings across studies and encourage high quality meta-analysis of individual patient data in the future. This may well constitute one of the most important steps forward in the field of clinical trials in TBI, paving the road for harvesting successful results in the near future.

\section{APPENDIX: MEMBERS OF THE WORKING GROUP DEMOGRAPHICS AND CLINICAL ASSESSMENT FOR DEVELOPMENT OF COMMON DATA ELEMENTS IN TBI}

P. David Adelson, Phoenix Children's Neuroscience Institute, Phoenix, Arizona

Tom Balkin, Walter Reed Army Institute of Research, Silver Spring, Maryland

Ross Bullock, University of Miami Miller School of Medicine, Miami, Florida

Doortje Engel, University Hospital Heidelberg, Germany

Wayne Gordon, Mount Sinai School of Medicine, New York, New York

Cindy Harrison-Felix, Craig Hospital, Englewood, Colorado

Jean Langlois, Dept. of Veterans Affairs, Rehabilitation Research and Development Service, Washington, DC 
Henry Lew, VA Boston Health Care System and Harvard Medical School, Boston, Massachusetts

Andrew Maas, University Hospital Antwerp, Belgium

David Menon, University of Cambridge, Cambridge, United Kingdom

Claudia Robertson, Baylor College of Medicine, Houston, Texas

Karen Schwab, Defense and Veterans Brain Injury Center, Washington, DC

Nancy Temkin, University of Washington, Seattle, Washington

Alex Valadka, Seton Brain and Spine Institute, Austin, Texas

Mieke Verfaellie, VA Boston Health Care System and Boston University School of Medicine, Boston, Massachusetts

Mark Wainwright, Northwestern University, Chicago, Illinois

David Wright, Emory University School of Medicine, Atlanta, Georgia

\section{REFERENCES}

1. Maas AI, Steyerberg EW, Murray GD, et al. Why have recent trials of neuroprotective agents in head injury failed to show convincing efficacy? A pragmatic analysis and theoretical considerations. Neurosurgery 1999;44:1286-1298.

2. Narayan RK, Michel ME, Ansell B, et al. Clinical trials in head injury. J Neurotrauma 2002;19:503-557.

3. Maas AIR, Marmarou A, Murray GD, Teasdale GM, Steyerberg EW. Prognosis and clinical trial design in traumatic brain injury: the IMPACT Study. J Neurotrauma 2007;24:232-238.

4. Maas AIR, Stocchetti N, Bullock R. Moderate and severe traumatic brain injury in adults. Lancet Neurology 2008;7:728-741.

5. Finkelstein EA, Corso PS, Miller TR, et al. The incidence and economic burden of injuries in the United States. 2006, New York: Oxford University Press.

6. Servadei F, Murray GD, Penny K, et al. The value of the "worst" computed tomographic scan in clinical studies of moderate and severe head injury. European Brain Injury Consortium. Neurosurgery 2000;46:70-7.

7. Chang EF, Meeker M, Holland MC. Acute traumatic intraparenchymal hemorrhage: risk factors for progression in the early postinjury period. Neurosurgery 2006;58:647-656.

8. Oertel M, Kelly DF, McArthur D, et al. Progressive hemorrhage after head trauma: predictors and consequences of the evolving injury. J Neurosurg 2002;96:109-116.

9. Harders A, Kakarieka A, Braakman R. Traumatic subarachnoid hemorrhage and its treatment with nimodipine. German tSAH Study Group. J Neurosurg 1996;85:82-9.

10. Xiao G, Wei J, Yan W, Wang W, Lu Z. Improved outcomes from the administration of progesterone for patients with acute severe traumatic brain injury: a randomized controlled trial. Critical Care 2008,12:R61.

11. Edwards P, Arango M, Balica L, et al. Final results of MRC CRASH, a randomized placebo-controlled trial of intravenous corticosteroid in adults with head injury-outcomes at 6 months. Lancet 2005;365:1957-1959.

12. Zhi D, Zhang S, Lin X. Study on therapeutic mechanism and clinical effect of mild hypothermia in patients with severe head injury. Surg Neurol 2003;59:381-385.
13. Lu LQ, Jiang JY, Yu MK, et al. Standard large trauma craniotomy for severe traumatic brain injury. Chin J Traumatol 2003;5:302304.

14. Jiang $\mathrm{J}, \mathrm{Xu} \mathrm{W}, \mathrm{Li} \mathrm{W}$, et al. Efficacy of standard trauma craniectomy for refractory intracranial hypertension with severe traumatic brain injury: a multicenter, prospective, randomized controlled study. J Neurotr 2005;22:623-628.

15. Jiang JY, Xu W, Li W, et al. Effect of long-term mild hypothermia or short-term mild hypothermia on outcome of patients with severe traumatic brain injury. J Cereb Blood Flow Metab 2006;26:771-776.

16. Clifton GL, Choi SC, Miller ER, et al. Intercenter variance in clinical trials of head trauma- experience of the National Acute Brain Injury Study: hypothermia. J Neurosurg 2001;95:751-755.

17. Maas AI, Murray G, Henney H 3rd, et al. Efficacy and safety of dexanabinol in severe traumatic brain injury: results of a phase III randomised, placebo-controlled, clinical trial. Lancet Neurol 2006; $5: 38-45$.

18. Bailey I, Bell A, Gray J, et al. A trial of the effect of nimodipine on outcome after head injury. Acta Neurochir (Wien) 1991;110: $97-105$.

19. European Study Group. A multicenter trial of the efficacy of nimodipine on outcome after severe head injury. The European Study Group on Nimodipine in Severe Head Injury. J Neurosurg 1994;80:797-804.

20. Grumme T, Baethmann A, Kolodziejczyk D, et al. Treatment of patients with severe head injury by triamconolone: a prospective, controlled multicenter clinical trial of 396 cases. Res Exp Med (Berl) 1995;195:217-229.

21. Young B, Runge JW, Waxman KS, et al. Effects of pegorgotein on neurologic outcome of patients with severe head injury. A multicenter, randomized controlled trial. JAMA 1996;276:538-543.

22. Marmarou A, Nichols J, Burgess J, et al. Effects of bradykinin antagonist Bradycor (Deltibant, CP-1027) in severe traumatic brain injury: results of a multi-center, randomized, placebo-controlled trial. J Neurotr 1999;16:431-444.

23. Yurkewicz L, Weaver J, Bullock MR, Marshall LF. The effect of the selective NMDA receptor antagonist traxoprodil in the treatment of traumatic brain injury. J Neurotr 2005;12:1428-1443.

24. Maas AIR, Steyerberg EW, Marmarou A, et al. IMPACT recommendations for improving the design and analysis of clinical trials in moderate to severe traumatic brain injury. Neurotherapeutics 2010;7:127-134.

25. Marmarou A, Lu J, Butcher I, et al. IMPACT database of traumatic brain injury: design and description. J Neurotrauma 2007;24:239250.

26. Braakman R, Schouten HJA, Blaauw-Van Dishoeck M, Minderhoud JM. Megadose steroids in severe head injury. J Neurosurg 1983;58:326-330.

27. Dearden NM, Gibson JS, McDowall DG, Gibson RM, Cameron MM. Effect of high-dose dexamethasone on outcome from severe head injury. J Neurosurg 1986;64:81-88.

28. Rockswold GL, Ford SE, Anderson DC, Bergman TA, Sherman RE. Results of a prospective randomized trial for treatment of severely brain-injured patients with hyperbaric oxygen. J Neurosurg 1992;76:929-934.

29. Wolf AL, Levi L, Marmarou A, et al. Effect of THAM upon outcome in severe head injury: a randomized prospective clinical trial. J Neurosurg 1993;78:54-59.

30. Gaab MR, Trost HA, Alcantara A, et al. "Ultrahigh" dexamethasone in acute brain injury. Results from a prospective randomized double-blind multicenter trial (GUDHIS). German Ultrahigh Dexamethasone Head Injury Study Group. Zentralbl Neurochir 1994;55:135-143.

31. Marshall LF, Maas AI, Marshall SB, et al. A multicenter trial on the efficacy of using tirilazad mesylate in cases of head injury. J Neurosurg 1998;89:519-525.

32. Robertson CS, Valadka AB, Hannay HJ, et al. Prevention of secondary ischemic insults after severe head injury. Crit Care Med 1999;27:2086-2095.

33. Morris GF, Bullock R, Bowers Marshall S, et al. Failure of the competitive N-methyl-D-aspartate antagonist Selfotel (CGS $19755)$ in the treatment of severe head injury: results of two phase III clinical trials. J Neurosurg 1999;91:737-743. 
34. Cooper DJ, Myles PS, McDermott FT, et al. Prehospital hypertonic saline resuscitation of patients with hypotension and severe traumatic brain injury. JAMA 2004:291:1350-1357.

35. Temkin NR, Anderson GD, Winn HR, et al. Magnesium sulfate for neuroprotection after traumatic brain injury: a randomized controlled study. Lancet Neurol 2007;6:29-38.

36. Cruz J, Minoja G, Okuchi K. Improving clinical outcomes from acute subdural hematomas with the emergency preoperative administration of high doses of mannitol: a randomized trial. Neurosurg 2001;49:864-871.
37. Cruz J, Minoja G, Okuchi K. Major clinical and physiological benefits of early high doses of mannitol for intraparenchymal temporal lobe hermorrhages with abnormal papillary widening: a randomized trial. Neurosurg 2002;51:628-638.

38. Mazzeo AT, Brophy G, Gilman CB, et al. Safety and tolerability of cyclosporin A in severe traumatic brain injury patients: results from a prospective, randomized trial. J Neurotrauma 2009 Jul 21 [Epub ahead of print].

39. Roberts I, Smith R, Evans S. Doubts over head injury studies. BMJ 2007:334:392-394. 